\title{
Eight principles of integrated pest management
}

\author{
Marco Barzman $^{1}$ - Paolo Bàrberi ${ }^{2}$ - A. Nicholas E. Birch ${ }^{3}$. \\ Piet Boonekamp $^{4}$ • Silke Dachbrodt-Saaydeh ${ }^{5}$ - Benno Graf ${ }^{6}$. \\ Bernd Hommel $^{7}$ • Jens Erik Jensen ${ }^{8}$. Jozsef Kiss ${ }^{9}$ • Per Kudsk ${ }^{10}$. \\ Jay Ram Lamichhane ${ }^{1}$ • Antoine Messéan ${ }^{1}$ - Anna-Camilla Moonen ${ }^{2}$. \\ Alain Ratnadass ${ }^{11} \cdot$ Pierre Ricci $^{12}$. Jean-Louis Sarah ${ }^{13} \cdot$ Maurizio Sattin $^{14}$
}

Accepted: 6 July 2015 / Published online: 24 July 2015

(C) INRA and Springer-Verlag France 2015

\begin{abstract}
The use of pesticides made it possible to increase yields, simplify cropping systems, and forego more complicated crop protection strategies. Over-reliance on chemical control, however, is associated with contamination of ecosystems and undesirable health effects. The future of crop production is now also threatened by emergence of pest resistance and declining availability of active substances. There is therefore a need to design cropping systems less dependent on synthetic pesticides. Consequently, the European Union requires the application of eight principles $(\mathrm{P})$ of Integrated Pest Management that fit within sustainable farm management. Here, we propose to farmers, advisors, and researchers a dynamic and flexible approach that accounts for the diversity of farming situations and the complexities of agroecosystems and that can improve the resilience of cropping systems and our capacity
\end{abstract}

Marco Barzman

marco.barzman@grignon.inra.fr

1 INRA, UAR1240 ECO-INNOV, Avenue Lucien Brétignières, F-78850 Thiverval Grignon, France

2 Scuola Superiore Sant'Anna, Institute of Life Sciences, Land Lab, Via Santa Cecilia 3, 56127 Pisa, Italy

3 The James Hutton Institute, Invergowrie, Dundee DD2 5DA, Scotland, UK

4 Plant Research International, Wageningen University, Postbus 69, 6700AB Wageningen, The Netherlands

5 Julius Kühn-Institut, Federal Research Centre for Cultivated Plants, Stahnsdorfer Damm 81, 14532 Kleinmachnow, Germany

6 Agroscope Changins-Wädenswil ACW, Plant Protection and Fruit and Vegetable Extension, Schloss 1, CP,

8820 Wädenswil, Switzerland to adapt crop protection to local realities. For each principle $(\mathrm{P})$, we suggest that $(\mathrm{P} 1)$ the design of inherently robust cropping systems using a combination of agronomic levers is key to prevention. (P2) Local availability of monitoring, warning, and forecasting systems is a reality to contend with. (P3) The decision-making process can integrate cropping system factors to develop longer-term strategies. (P4) The combination of non-chemical methods that may be individually less efficient than pesticides can generate valuable synergies. (P5) Development of new biological agents and products and the use of existing databases offer options for the selection of products minimizing impact on health, the environment, and biological regulation of pests. (P6) Reduced pesticide use can be effectively combined with other tactics. (P7) Addressing the root causes of pesticide resistance is the best way to find sustainable crop

7 Julius Kühn-Institut, Federal Research Centre for Cultivated Plants, Institute for Ecological Chemistry, Königin-Luise-Str. 19, DE 14195 Berlin, Germany

8 SEGES, 15 Agro Food Park, Skejby, 8200 Aarhus N, Denmark

9 Plant Protection Institute, Szent Istvan University, Pater K. street 1, H-2100 Gödöllö, Hungary

10 Department of Agro-ecology, Aarhus University, Forsoegsvej 1, Flakkebjerg, 4200 Slagelse, Denmark

11 CIRAD, Unité de recherche HortSys, TA B-103/C, Campus international de Baillarguet, F-34398 Montpellier Cedex 5, France

12 INRA, UMR1355 ISA, F-06903 Sophia-Antipolis, France

13 CIRAD, Direction Générale Déléguée à la Recherche et à la Stratégie, TA 179/04 Avenue Agropolis, F-34398 Montpellier Cedex 5 , France

14 National Research Council, Institute of agro-environmental and forest biology, Agripolis, 35020 Legnaro (Padova), Italy 
protection solutions. And (P8) integration of multi-season effects and trade-offs in evaluation criteria will help develop sustainable solutions.

Keywords Integrated pest management · Europe · Pesticides · Alternatives · Systems approach · Resilient cropping system $\cdot$ Sustainable agriculture

\section{Contents}

1 Introduction

2 On the overall implementation of Integrated Pest Management principles

2.1 Systems approach and dynamic nature of Integrated Pest Management

2.2 Non-technical factors of implementation

3 On the implementation of individual principles

3.1 Principle 1-Prevention and suppression

3.1.1 Combinations of tactics and multi-pest approach

3.1.2 Rotation

3.1.3 Crop management and ecology

3.2 Principle 2-Monitoring

3.3 Principle 3-Decision based on monitoring and thresholds

3.4 Principle 4-Non-chemical methods

3.5 Principle 5-Pesticide selection

3.6 Principle 6-Reduced pesticide use

3.7 Principle 7-Anti-resistance strategies

3.8 Principle 8-Evaluation

4 Conclusion

Acknowledgments

References

\section{Introduction}

Dependency on pesticides for the protection of crops is associated with undesirable effects on the environment, health, and the sustained efficacy of their use. The advent of synthetic pesticides has made it possible to simplify cropping systems and forego more complicated crop protection strategies. But this process threatens even the future of crop protection. In weed management, over-simplification of cropping systems coupled with over-reliance on chemical weed control exacerbated by the continuous and extensive use of few modes of action has led to widespread resistance to herbicides (Busi et al. 2013). The same phenomenon is observed with insects and pathogens. The declining number of available active substances favors the emergence of resistance. According to the European Commission, there were more than 1000 active ingredients authorized in 2001 while there were just over
250 in 2009 and the trend is still downwards (Jensen 2015). A study by the European Crop Protection Association showed that there were 70 new active ingredients in the development pipeline in 2000, while there were only 28 in 2012 (McDougall 2013). Integrated Pest Management (IPM) is increasingly perceived as a workable solution to these problems.

IPM has come a long way since the introduction of "integrated control" defined as "applied pest control which combines and integrates biological and chemical control" (Stern et al. 1959). The concept was initially developed by entomologists faced with indiscriminate broad-spectrum insecticide use and insect outbreaks caused by the elimination of natural enemies and the emergence of pesticide resistance. IPM now applies to all aspects of plant protection. It is the object of renewed attention as European policy, research, and extension efforts strive to mainstream it across the European Union. The EU Framework Directive 2009/128/EC on the sustainable use of pesticides takes on this challenge. It provides a definition of IPM largely inspired from the definition given by the Food and Agriculture Organization of the United Nations, substituting the concept of "pest control techniques" with "plant protection methods" and adding the notion of "ecological justification" to that of economic justification (Fig. 1). These recent modifications reflect an increasing interest in understanding and working with ecological processes. The EU Framework Directive requires that all EU Member States develop a National Action Plan which ensures that a set of eight general principles of IPM (Table 1) are implemented by all professional pesticide users starting January 1, 2014 (European Union 2009a). In addition to the Directive, Regulation 1107/2009/ EC on the placing of plant protection products on the market requires that pesticides be "used properly," where proper use "shall also comply with (...) general principles of integrated pest management (...)" (European Union 2009b). More simply put, the new set of legislation - the so-called "EU pesticides package" - which includes two Directives and two Regulations (Fig. 2), aims at risk reduction during the use phase of pesticides and demands that all pesticide users adopt IPM. IPM, however, is a multi-faceted approach drawing on many disciplines and involving several economic sectors. It is a difficult field when it comes to producing clear recommendations applicable to the diversity of European agriculture (Barzman et al. 2014).

In this paper, the authors, all of whom are members of the European network ENDURE (www.endure-network.eu), review the eight general principles of IPM from the angle of what their implementation means for research, farm advisory services, and farmers. Our aim is to encourage IPM practitioners to embrace the complexity inherent in the development of sustainable crop protection strategies. We provide arguments and examples on how the site-specific, dynamic, systemic, and knowledge-intensive nature of IPM can be taken into account and translated into workable 
Fig. 1 The definition of IPM provided by the European Union Framework Directive on the Sustainable Use of Pesticides (Directive 2009/128/EC)
'Integrated pest management' means careful consideration of all available plant protection methods and subsequent integration of appropriate measures that discourage the development of populations of harmful organisms and keep the use of plant protection products and other forms of intervention to levels that are economically and ecologically justified and reduce or minimise risks to human health and the environment. 'Integrated pest management' emphasises the growth of a healthy crop with the least possible disruption to agro-ecosystems and encourages natural pest control mechanisms. practices. Our view is that lasting robust and well-adapted strategies that effectively reduce reliance on pesticides cannot be encapsulated within recipe-like recommendations. For this reason, we do not provide a comprehensive "how to" guide or checklist on the implementation of each principle. Rather, along with the other seven principles, we particularly highlight Principle 1 on prevention, which in theory, takes precedence but often implies the most fundamental changes to current practices. Recognizing that for many covered horticulture and vegetable crops, biological control, climate control and soilless possibilities are already contributing to a high level of IPM; we do not focus on these crops. Instead, we have chosen to favor examples referring to present-day challenging domains of IPM application, such as arable crops.

\section{On the overall implementation of Integrated Pest Management principles}

\subsection{Systems approach and dynamic nature of Integrated Pest Management}

IPM is a holistic enterprise emphasizing a systems approach. It creates synergies by integrating preventive methods drawing from a diverse array of approaches. It builds on agronomic, mechanical, physical, and biological principles, resorting to selective pesticide use when addressing situations that cannot be successfully managed with other tools. Reliance on a wide diversity of solutions is needed to ensure the long-term sustainability of control measures. Otherwise, the continuous use of a single method against a given pest - authors consider "pests" to include "any species, strain or biotype of plant, animal or pathogenic agent injurious to plants or plant products" as defined by the International Plant Protection Convention (2010) - be it the most favorable solution initially, induces pest populations to evolve, adapt, and overcome the control method. Over-reliance on a single method can also cause a shift in the composition of a pest community towards species less susceptible to that method. The higher the selection pressure exerted by the control method, the more rapid the process. When it comes to research, extension, monitoring, evaluation, or the production of guidelines, IPM principles apply to cropping systems over an extended spatial and temporal scale, rather than to individual crops. Indeed, many of the levers that are key to achieving robust agroecosystems are to be found at the cropping system level and at larger scalesas in area-wide IPM and landscape ecology. Approaching the problem from a systems angle makes it possible to envision less vulnerable cropping systems, move away from curative control, and more fully apply Principle 1 on prevention and suppression of harmful organisms.

IPM takes different forms that vary in time and space. It is shaped according to site-specific factors such as regional cropping pattern, field size, type and availability of seminatural habitats, the broader landscape, cultivation practices, pest pressure, R\&D efforts, availability of training, farmer attitude, and economics. Benbrook et al. (1996) introduced the idea that farmers can evolve along an IPM continuum ranging from "no IPM" to "high or biointensive IPM". The continuum includes the integration of optimized pesticide use combined with non-chemical strategies in current crop production systems as well as more radical redesigns of production systems involving plant varieties, crop rotations, landscape features, and new technologies. The "Holy Grail" to reflect upon would be "ultimate IPM", an ideal — and perhaps unattainable - situation where the cropping system has been so well crafted that no crop protection intervention is needed once it is in place (Ratnadass and Barzman 2014). In the real world though, individual farmers practice IPM via a process of stepwise integration of innovative solutions over several years. Gradual adaptation enables them to meet changing pest threats, agricultural policies, and incentives. A study of arable farmers (Lamine 2011) showed that new practices modifying dose, sowing date, stand density, fertilizer application, use of growth regulators, and rotations are adopted piecemeal over time. One change leads to another resulting in fine-tuning of system level changes.

Researchers and farm advisers can develop lasting and stable strategies by extending crop protection over larger spatial and temporal scales via stepwise improvements with farmers.

\subsection{Non-technical factors of implementation}

Farmers do not adopt IPM strategies based solely on technical questions. The social and economic environment in which they operate is also critical. For example, advances in applied ecology show the benefits of increasing genetic diversity in a rotation (Ratnadass et al. 2012). But the decision to introduce a new cultivar or crop species also depends on the market, 
Table 1 ANNEX III of Framework Directive 2009/128/EC — general principles of integrated pest management. For ease of reference, authors added shorthand titles to each principle

Principle 1 - prevention and suppression

The prevention and/or suppression of harmful organisms should be achieved or supported among other options especially by:

- Crop rotation,

- Use of adequate cultivation techniques (e.g., stale seedbed technique, sowing dates and densities, undersowing, conservation tillage, pruning and direct sowing),

- Use, where appropriate, of resistant/tolerant cultivars and standard/ certified seed and planting material,

- Use of balanced fertilization, liming and irrigation/drainage practices,

- Preventing the spreading of harmful organisms by hygiene measures (e.g., by regular cleansing of machinery and equipment),

- Protection and enhancement of important beneficial organisms, e.g., by adequate plant protection measures or the utilizsation of ecological infrastructures inside and outside production sites.

Principle 2-monitoring

Harmful organisms must be monitored by adequate methods and tools, where available. Such adequate tools should include observations in the field as well as scientifically sound warning, forecasting and early diagnosis systems, where feasible, as well as the use of advice from professionally qualified advisors.

Principle 3-decision-making

Based on the results of the monitoring the professional user has to decide whether and when to apply plant protection measures. Robust and scientifically sound threshold values are essential components for decision-making. For harmful organisms threshold levels defined for the region, specific areas, crops and particular climatic conditions must be taken into account before treatments, where feasible.

Principle 4 - non-chemical methods

Sustainable biological, physical and other non-chemical methods must be preferred to chemical methods if they provide satisfactory pest control.

Principle 5-pesticide selection

The pesticides applied shall be as specific as possible for the target and shall have the least side effects on human health, non-target organisms and the environment.

Principle 6-reduced pesticide use

The professional user should keep the use of pesticides and other forms of intervention to levels that are necessary, e.g., by reduced doses, reduced application frequency or partial applications, considering that the level of risk in vegetation is acceptable and they do not increase the risk for development of resistance in populations of harmful organisms.

Principle 7-anti-resistance strategies

Where the risk of resistance against a plant protection measure is known and where the level of harmful organisms requires repeated application of pesticides to the crops, available anti-resistance strategies should be applied to maintain the effectiveness of the products. This may include the use of multiple pesticides with different modes of action.

Principle 8 - evaluation

Based on the records on the use of pesticides and on the monitoring of harmful organisms the professional user should check the success of the applied plant protection measures.

agri-environmental schemes, or retail chain procurement strategies (Lefebvre et al. 2014; ENDURE 2010a).
If market forces alone are not sufficient to promote sustainable practices, other economic incentives are feasible. Swiss agricultural policy provides an example of creating subsidies to mainstream integrated production. A 1996 amendment to the federal constitution included the principle of multifunctionality and sustainability in the agricultural sector. Swiss growers are now required to conserve natural resources, foster biodiversity, minimize pollutant emissions, and tend an attractive landscape. The proportion of Swiss agriculture registered as contributing ecological services now reaches $98 \%$ of the production area, $88 \%$ of which is under integrated production, and $12 \%$ under organic agriculture (BLW 2013). Information flow, level of cooperation, and inclusion of a diversity of viewpoints have been shown to influence adoption of environmentally friendly practices as much as economics (Schenk et al. 2007). The social capital and involvement of farmers in professional networks can explain engagement in environmental schemes (Mathijs 2003) and adoption of low input practices (Nave et al. 2013). A social sciences study (ENDURE 2010b) showed that nearly all farmers moving along the continuum were active members of farmer organizations, whereas isolated farmers were less likely to engage in IPM. In farmer groups, members learn from one another, from advisers, and from researchers. They gain confidence by confronting their decisions to others, coconstruct locally adapted solutions, and change the way they assess performance.

IPM is knowledge-intensive, and farm advisory services have an important role to play in promoting multi-actor interactions, information flow, and the production of locally pertinent knowledge. Farm advisory services can be more efficient in helping to reduce reliance on pesticides when acting as independent agents. They have the capacity to facilitate exchange and learn between different farmer communities, including conventional and organic ones. They can support multi-actor groups that include farmers, advisers, researchers, and other stakeholders. Collective advisory approaches have been successfully implemented in a number of European countries. Back in 1976 in Switzerland, it was farmeradviser-researcher groups that devised alternative crop protection strategies which eventually developed into the integrated production guidelines that became mainstream nationally (Stäubli 1983). In Hungary, an IPM program against the Western corn rootworm, Diabrotica virgifera virgifera LeConte, achieved agreements between farmers regarding location and maximum surface area under maize production for landscape-level IPM management of that pest (Papp Komáromi et al. 2007). In Denmark, "experience groups" consisting of cross-visits and discussions among 10 growers facilitated by a farm adviser over a full growing season stimulate participatory learning, friendly competition, and social interactions. The approach yielded reduced pesticide doses and lower advisory costs (Kudsk and Jensen 2014). France 
Fig. 2 The suite of 2009 European Union legislation known as "The Pesticides Package"

\section{Official Journal of the European Union}

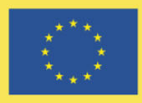

English edition

Legislation

DIRECTIVE 2009/128/EC OF THE EUROPEAN PARLIAMENT AND OF THE COUNCIL of 21 October 2009

establishing a framework for Community action to achieve the sustainable use of pesticides

REGULATION (EC) No 1107/2009 OF THE EUROPEAN PARLIAMENT AND OF THE COUNCIL of 21 October 2009

concerning the placing of plant protection products on the market and repealing Council Directives

DIRECTIVE 2009/127/EC OF THE EUROPEAN PARLIAMENT AND OF THE COUNCIL of 21 October 2009

amending Directive 2006/42/EC with regard to machinery for pesticide application

REGULATION (EC) No 1185/2009 OF THE EUROPEAN PARLIAMENT AND OF THE COUNCIL of 25 November 2009

concerning statistics on pesticides set up an ambitious demonstration network totaling 1900 commercial and experimental farms in 2012. The network is dedicated to generating and sharing information on the technical and economic feasibility of reducing reliance on pesticides (DGAL 2014). Most arable cropping systems under scrutiny reduced their treatment frequency index by at least $10 \%$. Economic analyses show no antagonism between pesticide use reduction and profit (Pillet 2014). Germany recently set up a system of demonstration farms in a number of crops where farmers supported by scouts, advisors, and scientists change their cropping practice and voluntarily apply a selfauditing assessment tool (Peters et al. 2013). Initial results from the demonstration farms show that, although labor-intensive, monitoring support and guidance does translate to reduced pesticide use (Freier et al. 2012). The data collected during the 2012-2013 season show that the treatment frequency index in winter wheat, winter barley, and winter oilseed rape was significantly lower in the demonstration farms relative to the reference farms (Peters M. pers. communication). In the UK, the Linking Environment and Farming partnership program has set up demonstration farms and research innovation centers to promote on-farm IPM uptake associated with environmental self-audit tools (LEAF 2013).

For future generations of farmers, advisers, and retailers, learning in institutions of higher education also plays an important role. European Union Member States could gradually include IPM knowledge in their university and technical school curricula.

The eight principles of IPM are not designed to address the social and economic aspects of IPM implementation or the organization of farm advisory services. Nevertheless, these non-technical factors constitute valuable actionable levers.

The successful implementation of IPM depends on nontechnical aspects such as economics, the social environment of farmers, farm advisory services, and collective multi-actor approaches, which deserve more attention.

\section{On the implementation of individual principles}

Framework Directive 2009/128/EC requires that all Member States show how their National Action Plans ensure the implementation of the eight general principles of IPM, and Article 55 of Regulation 1107/2009/EC requires that professional pesticide users comply with these principles. Beyond the legal requirement, the authors believe that the set of general principles provides valuable guidance encouraging growers along a logical process of decision-making. Intelligent application of the principles can be taken as an opportunity to both reduce dependency on pesticides and innovate.

The eight principles and their numbering actually result from a logical sequence of events. Figure 3 illustrates this 


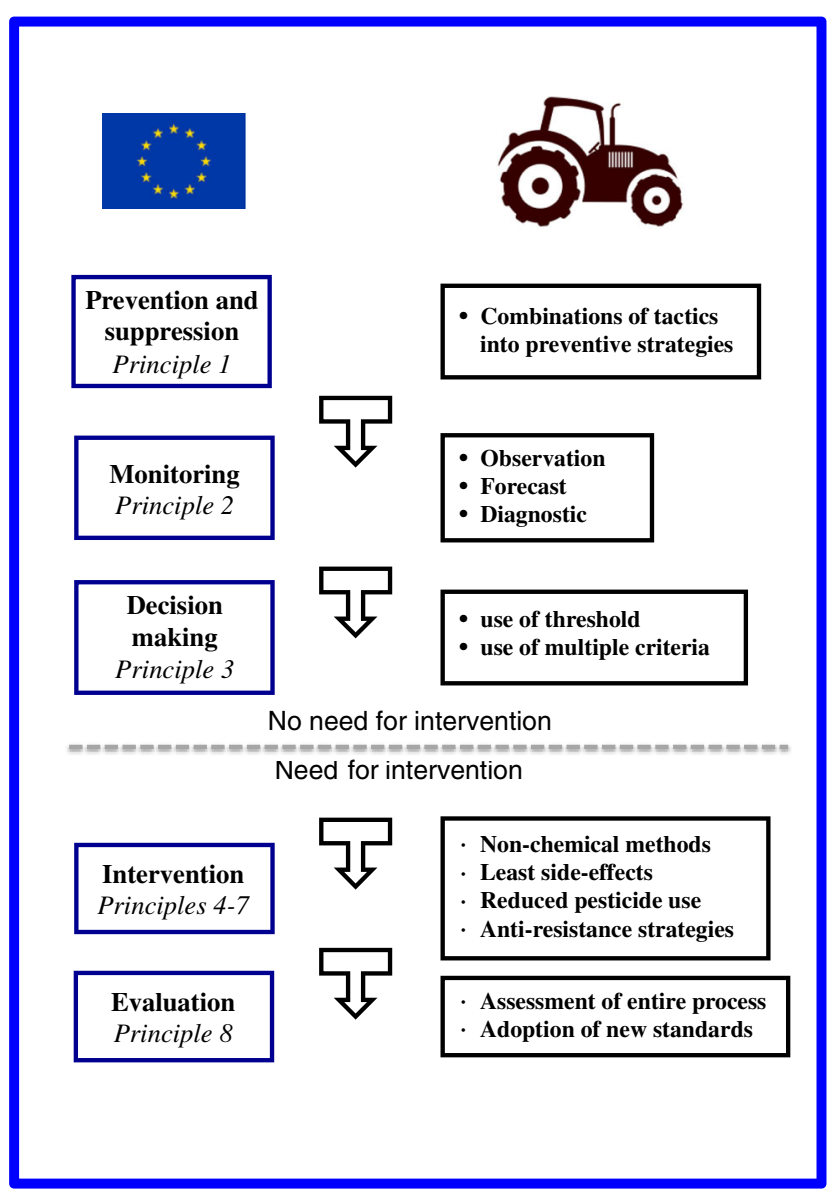

Fig 3 The sequential rationale behind the eight principles of IPM (P1P8). Adapted from Draft Guidance Document for establishing IPM principles, 2008, Directorate General for the Environment and Beratungsgesellschaft für integrierte Problemlösungen

sequence. Principle 1 (Prevention and suppression) comes first because it encompasses the initial design and actions undertaken at the cropping system level to reduce the severity and frequency of pest outbreaks. Principles 2 (Monitoring) and 3 (Decision-making), which come into play once the cropping system is in place, are based on the idea that inseason control measures result from a sound decisionmaking process that takes into account actual or predicted pest incidence. In the event that an intervention is decided, Principles 4 to 7 offer a sequence of control options that can be explored starting with the least preoccupying ones first. Principle 8 (Evaluation) closes the loop by ensuring that users look back and assess their actions in view of improving the entire process.

\subsection{Principle 1—prevention and suppression}

"Prevention is better than cure" is the first general rule in any production system. Prevention can be considered as the creation of cropping systems inherently less likely to experience significant economic losses due to the presence of pests.
Suppression, understood as the reduction of the incidence of pests or of the severity of their impact, complements prevention. This principle means that the aim is not to completely eliminate pests but to prevent any single one from becoming dominant or damaging in a cropping system.

Certain aspects of prevention dealing with the use of healthy and weed-free planting material and detection of pathogens in substrates deserve more attention, particularly in light of new technologies. Many pathogens associated with seed become the source of disease in the subsequent year. Weed seed contaminating harvest can become a major problem in the subsequent year. Certification of disease-free seed, seed potatoes, bulbs, cuttings, and new sorting technologies are very helpful in avoiding problems but it is important to apply measures early, prior to certification of harvested seed (Van der Wolf et al. 2013). Soil substrates, manure, and other amendments can now be screened with modern molecular multiplex technologies to qualitatively and quantitatively assess the disease situation (Van Gent-Pelzer et al. 2010; Sikora et al. 2012). Such diagnostic allows better decision-making regarding the choice of subsequent crops or cultivars. Been et al. (2005) developed a web-based tool that potato farmers can use to fine-tune their rotation strategies based on the detection of certain nematode pathotypes. For the detection of pathogens in latently infected seed and plants, however, new technologies with higher sensitivity are needed.

Plant breeding for pest resistance is recognized as an important contributor to the development of prevention strategies. The use of pest-tolerant and resistant cultivars will help to decrease dependence on pesticides in arable crops. However, absolute resistance to a specific pest in crops is not a realistic goal. Even resistance by pyramiding resistance genes in one cultivar can be overcome if no other measures to reduce selection pressure are applied. To avoid such an outcome, the use of new cultivars needs to be combined with continuous monitoring of emerging virulent biotypes and pathogens carrying resistance-breaking genes. Haverkort et al. (2008) showed the feasibility of this approach against Phytophthora in potato.

\subsubsection{Combinations of tactics and multi-pest approach}

The combination of control tactics into management strategies generates more effective and sustainable results than singletactic approaches. To create conditions that reduce the frequency and intensity of pest outbreaks, research and extension need to develop strategies integrating a range of methods. Plant genetic resistance can be exploited while addressing multiple pests, diversifying cropping systems in time and space, and integrating crop management practices and landscape effects within pest management. Even though testing such integrated strategies requires careful planning and relatively high investment, it is feasible. The FP7 PURE project 
Fig. 4 Principle 1-Diversifying crop rotation in arable crops as a preventive strategy

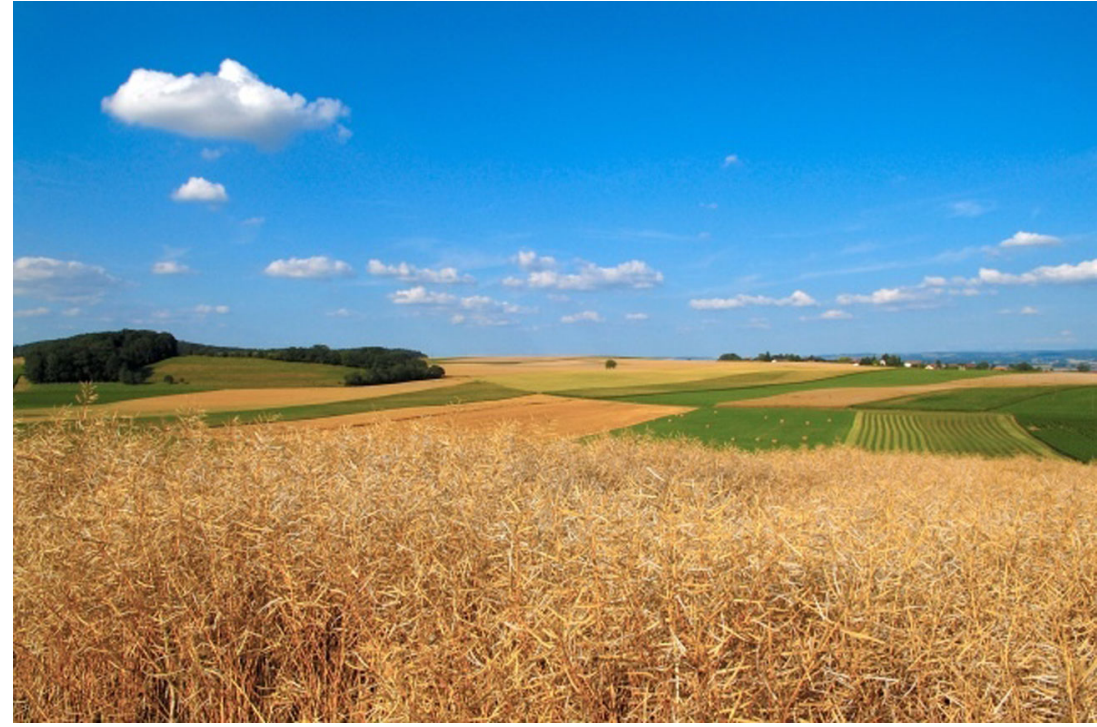

(Pesticide Use-and-risk Reduction in European farming systems with Integrated Pest Management, www.pureipm.eu) evaluates the feasibility of combinations on six different cropping system types. This European project successfully tested various combinations integrating the following tactics in maize-based cropping systems: foregoing pre-emergence herbicides, establishing a false seedbed, harrowing at the 2-3 leaf stage, use of low-dose post emergence herbicide, hoeing combined with postemergence band-spraying, and Trichogramma releases against European corn borer, Ostrinia nubilalis (PURE 2013).

When feasible, control strategies take into account multiple pests as control of one pest may affect others. In the UK, the Hortlink SCEPTRE 4-year, multi-crop, multi-season, multi-pest project tested on-farm is a combination of options against aphids, raspberry beetle, and Botrytis drawing from pest-resistant varieties, biocontrol agents, precision monitoring, and biopesticides for protected raspberry systems (Horticultural Development Company 2012). The optimal combination in each region reduced



Fig. 5 Principle 2-Pheromone traps are commonly used in orchards to monitor lepidopteran pests of fruit pesticide inputs by at least $30 \%$ and provided as good pest suppression as current pesticide-based practice. The further development of multi-pest recommendations requires that scientific research, on-farm testing, and advisor/farmer education programs move away from the compartmentalized study of weeds, insects, and pathogens. On-farm and whole-farm initiatives cutting across scientific disciplines are needed to take into account arthropod-weed-pathogen complexes and devise solutions that are workable from the farmer's point of view.

\subsubsection{Rotation}

Spatial and temporal diversification is key to minimizing pest pressure and achieving effective prevention. In organic arable crop farming, crop rotation is the most effective agronomic alternative to synthetic pesticides (Fig. 4). In annual crops, the manipulation of crop sequence to break the life cycle of pests through rotation with crop species belonging to different

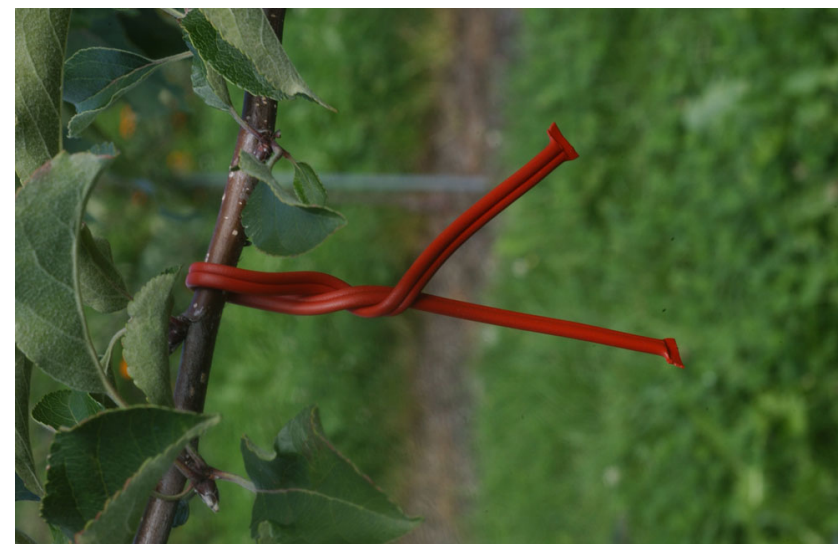

Fig. 6 Principle 4-Pheromone mating disruption is an alternative to chemical control against several lepidopteran pests of fruit 
Fig. 7 Principle 4-Mechanical weeding is a major alternative to herbicide use

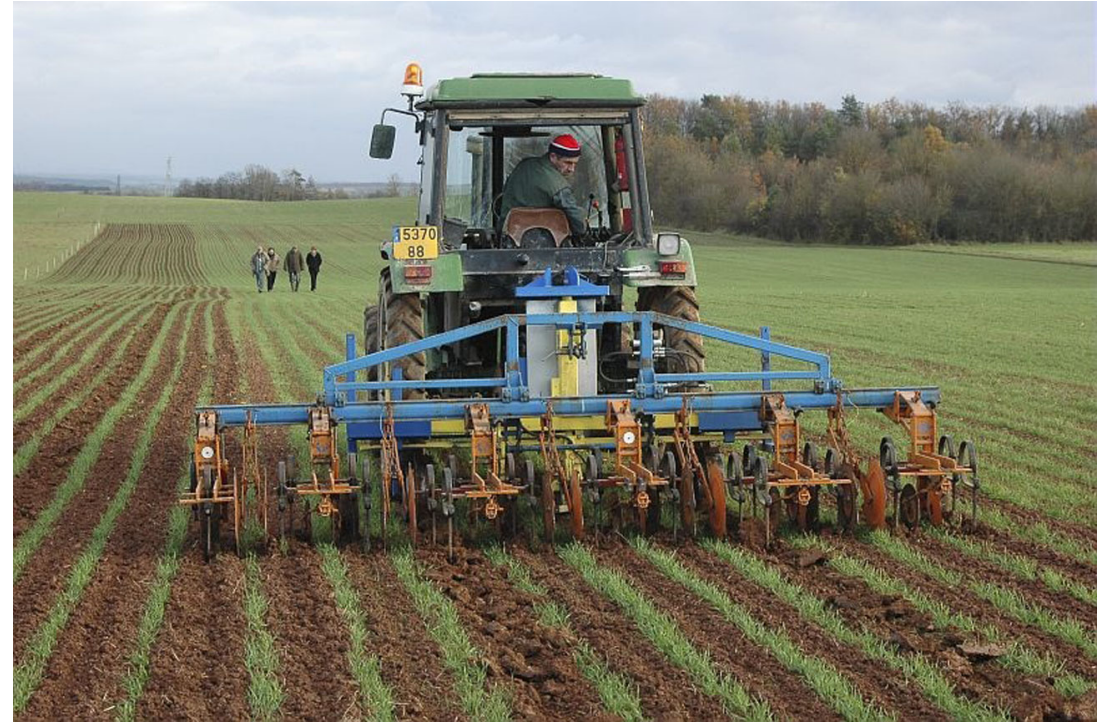

families is a major lever to strengthen robustness of cropping and farming systems. In this context, robustness refers to stabilizing agronomic performance in spite of disturbances caused by the presence of pests. A diversified crop sequence prevents selection and buildup of the best-adapted pest populations. As a general rule in arable crop rotations, alternating winter and spring-summer crops is recommended as this will break the life cycle of many pests, particularly weeds, more efficiently than a rotation with just winter or summer crops. Similar principles can also be developed for vegetable cropping systems where rotation between leaf and root crops is promoted, while the frequent occurrence of crops within the same botanical family is discouraged. For many specialist fungal pathogens, the selection of different crop families within a rotation effectively reduces pressure. There are other plant pathogens characterized by broad host range that need to be treated differently, however. Such is the case of the bacteria
Pseudomonas syringae (Bartoli et al. 2014; Lamichhane et al. 2014a) and Xanthomonas arboricola (Lamichhane 2014) which infect a number of botanical families.

Maize-based cropping systems offer an illustration of the importance of crop rotation. Continuous maize cultivation is widespread in Europe for grain production as well as for silage and energy production. Rotation has been demonstrated as key to reducing reliance on pesticides while allowing the successful management of the invasive Western corn rootworm Diabrotica virgifera virgifera as well as several noxious weeds (Vasileiadis et al. 2011). In Europe, the Western corn rootworm can be considered as a pest of a specific maize cultivation system because the complete egg-to-adult development of the pest extends through two maize cultivation cycles. When maize is rotated with a non-maize crop, the cycle of this pest is broken and its population decreases to minimal levels. Because of the multiple on-farm uses of maize
Fig. 8 Principle 5-Protecting honeybees is one criterion used for pesticide selection

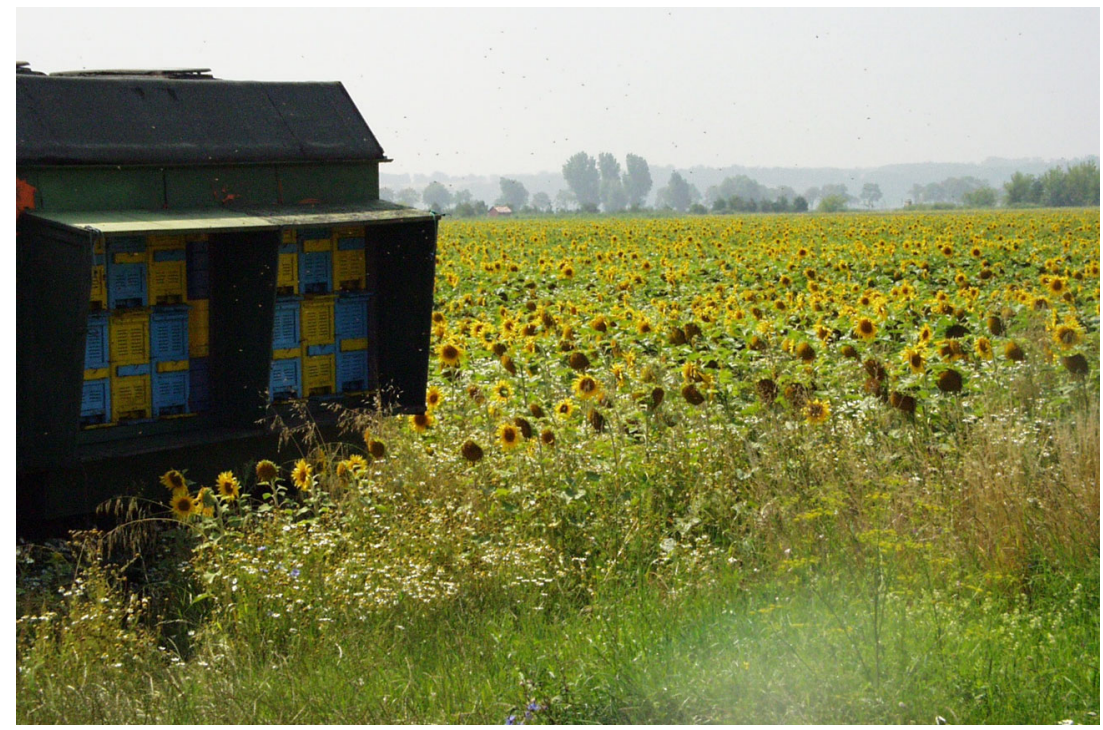


and the profits it generates, introduction of a new crop nevertheless requires careful market considerations and additional inputs in terms of knowledge and machinery (Vasileiadis et al. 2013). The rotation rule is therefore applied in a flexible way, adapting it to local conditions and allowing more frequent maize crops in a rotation and wider occurrence per farm area than theoretically optimal (Levay et al. 2014; Szalai et al. 2014). Rotating maize to a diversity of non-maize crop species helps farmers avoid the development of variant of the Western corn rootworm that is referred to as "rotation resistant" because of its propensity to oviposit in non-maize crops. The maize-soybean rotation in the US corn belt routinely applied over large areas for many years has selected for a strain that has lost its preference for laying eggs in maize, resulting in damage in maize following soybean crops (Levine and Oloumi-Sadeghi 1996; Gray et al. 1998; Levine et al. 2002).

\subsubsection{Crop management and ecology}

Many crop management practices apparently unrelated to pest management actually have a significant impact on the vulnerability of cropping systems to pests. Fertilization is known to affect sap-sucking insects and mites (Altieri and Nicholls 2003), plant pathogenic fungi (Snoeijer et al. 2000), and bacteria (Lamichhane et al. 2013). Mechanical weeding can damage crop tissue and favor diseases (Hatcher and Melander 2003). Crop residue management can affect the overwintering capacity of pests (Sojka et al. 1991). Tillage systems often determine abundance and composition of weed communities and soil-borne diseases (Norris 2005).

Conservation tillage is referred to under Principle 1 as a desirable cultivation technique. Its role within IPM, however, is not always clear-cut. While it is true that reduced tillage does favor soil organic matter and biodiversity, and that it reduces $\mathrm{CO}_{2}$ emissions and risks of soil erosion, the supposed benefits for crop protection cannot be generalized. For example, Fusarium blight, one of the main causes of mycotoxins, is greatly favored by no-till systems where maize and wheat residues remain on the soil surface year-round (Kandhai et al. 2011). Also, no-till systems are usually associated with greater herbicide dependency — due to "chemical mowing" prior to sowing - and conditions more favorable to the evolution of herbicide resistance (Melander et al. 2012). The benefits of conservation tillage need to be assessed relative to multiple sustainability criteria generating trade-offs. Here, as is often the case in IPM, it is difficult to generate simple and general recommendations-local fine-tuning is more pertinent.

Increasing inter- and intra-specific diversity within and around the cultivated field is gaining increased attention as a crop protection strategy. There are many strategies to increase spatial diversity. These include the use of mixed cultivars, composite cross-populations (i.e., crop populations obtained by continuously exposing a population rather than individual plants to natural selection), intercropping (i.e., the spatial association of two or more crop species), living mulches, or semi-natural vegetation. Significant disease reduction was obtained by interspacing a rice cultivar susceptible to Magnaporthe oryzae - causing rice blast-with a resistant one (Zhu et al. 2000; Raboin et al. 2012). Sapoukhina et al. (2013) used modeling techniques to demonstrate that mixing wheat cultivars using small proportions of highly resistant ones could more effectively reduce disease severity against multiple diseases while exerting low selective pressure on pathogens. A high level of crop genetic diversity can be obtained by using many parental lines to generate composite cross-populations and by ensuring that the resulting populations are continuously adapted to local conditions. In wheat, such composite cross-populations were shown to decrease outbreaks of the leaf spot disease complex (a combination of Tan Spot, Pyrenophora tritici-repentis, Septoria leaf blotch, Mycosphaerella graminicola, and Stagonospora leaf blotch, Parastagonospora nodorum), relative to single commercial varieties or variety mixtures (Costanzo 2014). Similar patterns have been reported for composite cross-populations of barley (Saghai Maroof et al. 1983). Intercropping different crop species can be used to reduce severity of diseases (FernandezAparicio et al. 2010; Gao et al. 2014). In perennial systems, living mulches can be successfully established for the control of weeds (Baumgartner et al. 2008; Fourie 2010). Some plant species can act as trap crops (Aluja et al. 1997), or as sources of natural enemies providing top-down control (Paredes et al. 2013). There are many such mechanisms by which increasing plant diversity can be taken advantage of to improve biological regulation of pests, but this approach has received more attention in tropical systems (Crowder and Jabbour 2014; Ratnadass et al. 2012). The "push-pull" strategy successfully implemented in Eastern Africa is an example of this approach. It is based on repelling the stem borer from maize - the main crop-by intercropping it with the leguminous plant silverleaf desmodium and simultaneously attracting the borer to a border strip planted with Napier grass, which acts as a dead-end trap crop. Silverleaf desmodium not only reduces stem borer attack on maize but also increases stem borer parasitization rates and suppresses the parasitic Striga weed via an allelopathic effect as well (Cook et al. 2007; Khan et al. 2010).

Preventive strategies designed to create a healthy, robust cropping systems require effective integration of multiple agronomic levers to reduce reliance on pesticide use.

\subsection{Principle 2 -monitoring}

Beyond prevention, moving away from a pesticide-based strategy implies monitoring harmful organisms at regular intervals (Fig. 5) or upon issue of local warnings. In an ideal world, all farmers would monitor pest populations and use forecasting 
systems prior to making a decision regarding control. The current reality, however, is that warning and forecasting systems are not available and affordable in all countries for all crops. Some countries have nevertheless developed successful support systems. In Denmark, an extensive monitoring system linked to the farm advisory system plays a major role in placing that country among the lowest pesticide users in arable crops in the European Union (Kudsk and Jensen 2014). In Germany, an online forecasting platform (das Informationssystem Integrierte Pflanzenproduktion www.isip.de) that integrates weather data in disease models provides regional decisionsupport in major crops (Racca et al. 2011). In Switzerland, farmers rely on weekly regional plant protection recommendations and online pest and disease forecasting systems and decision-support tools (www.phytopre.ch, www.agrometeo. ch, www.sopra.admin.ch) to assess risks for a variety of crops and, if need be, optimize timing of applications (Samietz et al. 2011). In France, for each region and cropping system, information on pest pressure collected by 4000 observers covering 15,400 plots is made freely available via a weekly update produced by multi-actor regional groups (DGAL 2014). This system has recently been enriched with data on non-intentional effects of pesticide use including monitoring of biodiversity trends via four indicator groups of species as well as monitoring of pesticide resistance in 30 pest and active substance associations.

The Europe-wide monitoring of the potato late blight pathogen, Phytophthora infestans, is an example of a welldeveloped multi-country monitoring system. Researchers from the UK, The Netherlands, and Denmark developed a DNA-fingerprinting method based on microsatellite markers. Within the EuroBlight network (www.EuroBlight.net), pesticide companies, advisors, and farmers participate in sampling and analyzing infected leaves. This extensive sampling network makes it possible to visualize the distribution of dominant pathogen clones, their virulence, the development of fungicide resistance, and the dynamics over several years and several areas of Europe.

Farmers are often reluctant to monitor weeds because they look similar at the young growth stages when management decisions are needed. While the level of infestation of most pathogens and insect pests will significantly vary between years, shifts in weed flora - except for herbicide-resistant biotypes - occur slowly (Walter 1996). The gradual year-to-year changes in weed populations makes it possible to generate weed maps by monitoring end-of-season weeds or by establishing small untreated plots in the field. The information collected in this way can then be used to plan weed management in the subsequent crops.

The availability and nature of monitoring, warning, and forecasting systems vary according to the type of pest and the means locally available. Researchers, advisers, and farmers are faced with the challenge of adapting to such a diversity of situations.

\subsection{Principle 3-decision based on monitoring and thresholds}

While it is true that sound intervention thresholds play an important role in IPM, they are, however, not always applicable, available, or sufficient. In many cases, thresholds have not been established for weeds (Sattin et al. 1992). This is also the case for pathogens, particularly those that switch from a saprophytic to a pathogenic lifestyle depending on environmental events and climatic conditions (Underwood et al. 2007).

In the past, many IPM programs have centered on threshold-based decisions. When decision-support systems are not in place or are not appropriate, however, the use of thresholds along with the concept of IPM are disregarded. It may be better in such cases to stress the importance of observation in general, of sound decision rules, and of the entire set of IPM principles.

IPM historically emerged in the area of insect pest control where the use of intervention thresholds has generated good results. The practicability of threshold-based decisions against diseases and weeds now needs to be demonstrated and reconsidered. Although there have been efforts to define economic thresholds for weeds (Keller et al. 2014), there is no consensus regarding their applicability. Developing thresholds for weeds is a challenge because they usually appear as a community of multiple species, typically have a patchy distribution, and have long-term impact through a persistent seed bank. Similarly, the pertinence of the threshold approach can be questioned in the case of polycyclic diseases, where it is often necessary to target the primary cycle while the inoculum level is very low and disease symptoms invisible. Conversely, thresholds may not apply in the case of tolerant varieties that can exhibit visible disease symptoms that do not in reality impact yield. We cannot realistically assume that robust and scientifically sound economic injury levels will be available for all major pests in all major crop varieties and cultivation environments. Complexity, regional and site specificities, emerging and invading pests, differing crop management practices, and ideally, the integration of externalities make that impossible. Principle 3, which requires growers to assess pest pressure, is important but not sufficient to ensure integration of all available measures. With respect to this last point, there may be an opportunity to develop a new generation of decision-support systems. Whereas present-day decision-support systems are usually based on real-time tactical decisionmaking involving one crop, one pest, and one control technique, new systems could support strategic approaches encompassing the whole range of IPM options. Instead of "spray/don't spray" guidance, the new systems would provide insights on desired varieties, cropping sequences, 
combinations of direct control methods, and relevant agronomic practices. They could also provide information on expected damage and economic consequences as well as on impacts on non-target and beneficial organisms.

The decision-making process determining ins eason control measures based on the short-term pest situation could be extended to integrate more systemic factors for longer-term strategic design.

\subsection{Principle 4-non-chemical methods}

Giving preference to non-chemical over chemical methods, if they provide satisfactory pest control, appears to be a sound and straightforward principle. The difficulty lies in the way "satisfactory pest control" is determined. The authors believe that the highest level of control attainable by chemical measures is often not sustainable, creates new pest problems, and is not a proper standard against which single non-chemical tactics are evaluated, rather, a satisfactory while sustainable level of pest management can be achieved via a broad IPM strategy that includes an array of protection methods. Separately, each alternative method, e.g., a biopesticide, may perform with lower and slower biocidal power and appear more costly than synthetic pesticides if externalities are not included. Collectively, however, alternative methods should generate synergies resulting in satisfactory pest management. Their cost could become more attractive if pesticide steering taxes currently under consideration in several European countries are introduced. More on the evaluation of protection measures is provided below under Principle 8 .

There is a wide range of non-chemical but direct pest control measures such as soil solarization or biological control, but their availability, efficacy, or pertinence varies considerably. Though various biotechnical methods have been developed, pheromone-based mating disruption is probably the most advanced and successful of such techniques (Fig. 6). Key insect pests of apple and grape such as codling moth, summer fruit tortrix, smaller fruit tortrix, and grapevine moths are effectively controlled with mating disruption. In Switzerland, the technique is in use in $50 \%$ of the apple orchards and $60 \%$ of the vineyards and has enabled a reduction of synthetic pesticide use by two thirds (Samietz and Höhn 2010; Günter and Pasquier 2008).

The use of live natural enemies represents a major nonchemical IPM tool that could be further developed. Whereas biological control agents are well developed in protected crops, significant opportunities for their use still exist in other systems such as arable crops. The use of Trichogramma against the European corn borer Ostrinia nubilalis is one of the few successful examples. The target specificity of natural enemies is an environmental asset that nevertheless presents challenges for biocontrol producers who are not assured high returns on their investment. Also, the use and handling of biological control agents require fine-tuning and specific skills best addressed via public-private research initiatives, education, and training (ENDURE 2010c). Innovative screening protocols that focus on important factors beyond mere efficacy will make it possible to tap into promising taxa of microorganisms outside the presently limited source of biodiversity (Kohl et al. 2011). Beyond the production and marketing of live biological agents, the cropping system and the landscape into which these organisms are released also needs to be taken into account to optimize and sustain their efficacy. There is a growing interest in better understanding ecological processes at the landscape level to achieve area-wide IPM based on the action of natural enemies. Rusch et al. (2010) have begun to study these aspects in the context of rotations involving oilseed rape.

For weeds, where biological control options seldom apply, many effective agronomic, mechanical, and physical control methods are available. They can be incorporated into Integrated Weed Management strategies to reduce impact of weeds and over-use of conventional herbicides over the longterm. Ideally, such strategies integrate preventive, cultural, and direct chemical or non-chemical tactics. A number of nonchemical direct methods such as suppressive winter cover crops, stale seedbed technique, pre-emergence cultivation, more dense crop stands, interrow precision weeding, and use of hoes equipped with tools for intra-row weeding are feasible (Fig. 7). They have been successfully applied in maize-based cropping systems and other row crops without jeopardizing yield (Vasileiadis et al. 2011). There is still a need to work out strategies based on knowledge of weed biology and the ecology of crop weed interactions that combine crop rotation, cultural control, non-chemical control methods, and chemical control using smart application technologies and adapt them to local circumstances. Direct non-chemical measures can cause undesired effects on other components of the pest-weed-disease complex. Changes in pest management could therefore be associated with monitoring of secondary pests.

The effective use of non-chemical alternatives requires a new mindset seeking synergies gained from the combined effect of alternative methods that may individually be less efficient or convenient than synthetic pesticides.

\subsection{Principle 5-pesticide selection}

IPM seeks to reduce reliance on pesticides. When prevention and alternative control methods by themselves do no yield satisfactory results, however, selective pesticides are also used. In this situation, Principles 5, 6, and 7, which presuppose pesticide use, become relevant. Sound selection of pesticides to minimize unwanted health or environmental effects (including negative effects on pest regulation) is essential (Fig. 8).

The undesired non-target impacts of broad-spectrum insecticides on arthropod natural enemies are well documented. In 
Switzerland, in the early 1970s, the excessive use of nonselective pesticides in orchards and vineyards nearly eradicated predatory mites and caused acaricide resistance among spider mites. Uncontrollable spider mite outbreaks could only be regulated with a pest control program specifically designed to preserve naturally occurring but reintroduced predatory mites (Stäubli 1983). To minimize disruption of biological control of pests and improve IPM, products more compatible with beneficial arthropods are favored. Databases can be consulted online for this purpose. They include the IOBC Pest Select Database, the IPM Impact Side-effects database (available on subscription), the Pesticide Action NetworkNorth America's pesticideinfo.org, the University of Hertfordshire's Pesticide Properties DataBase, or the French Ministry of Agriculture's E-phy catalogue (in French). Biological agent commercial companies-such as Koppert or Biobest - also provide information covering pesticide effects on the beneficial arthropods they deliver. Alternatives to more persistent molecules are being developed (Czaja et al. 2015; Gerwick and Sparks 2014). Selective biopesticides represent a particularly desirable alternative to chemical pesticides, but a wider range of such products needs to be made available. Some biopesticides are available on the market, but the number of bioherbicides remains low (Cantrell et al. 2012). The further development of biopesticides faces the same regulatory constraints as their synthetic pesticide counterparts as they fall under the same regulations (Villaverde et al. 2014).

Italy's Emilia-Romagna region has historically emphasized this principle in its agricultural development policy and obtained significant improvements during the last 25 years. IPM regulation and implementation in that region tackled both pesticide quantity and quality with the aim of reducing impact on human health and the environment while maintaining economically acceptable production. Only pesticides with a lower impact on human health and the environment were allowed in the new IPM system. As a result, 70 to $90 \%$ of the pesticides with high acute toxicity and 40 to $95 \%$ of those with a high chronic toxicity were excluded, and the overall quantity of pesticides used was reduced by 20-35\% between 1995 and 2005 (Galassi and Sattin 2014).

A number of existing databases and the further development of biopesticides offer desirable options for the selection of products minimizing impact on human health, the environment, and biological regulation of pests.

\subsection{Principle 6-reduced pesticide use}

Reducing doses, application frequency, and resorting to partial application of pesticides contribute to the IPM goal of reducing or minimizing risks to human health and the environment. In fact, national pesticide plans have adopted reduced use as their overall quantitative time-bound goal. Expressing reduction in terms of volume used automatically generates a downward trend due to a switch to more potent products. To circumvent this artifact, Denmark pioneered the "treatment frequency index," which simultaneously computes frequency of use and dose (Kudsk and Jensen 2014). Although the present authors consider reducing dose rates as secondary to reducing reliance on pesticides, we acknowledge it as a tactic along the IPM continuum that can be judiciously combined with other ones: use of resistant cultivars, applying thresholds concerning disease intensity rather than frequency combined with advanced decision-support systems. One aspect to consider applying reduced doses is the potential influence on the risk of pesticide resistance developing in the pest population, which is the focus of the next principle.

Reduced pesticide use, in terms of frequency, spot spraying, or dose reduction is a recognized tactic along the IPM continuum that can be combined with other ones.

\subsection{Principle 7—anti-resistance strategies}

The number of pest species resistant to pesticides is increasing and jeopardizing the efficacy of many products. The resistance of insect pests to insecticides was a major initial driver for the development of IPM (Stern et al. 1959). There are now many instances of resistance among all pest categories. For example, Podosphaera xanthii, the fungus causing cucurbit powdery mildew quickly developed resistance to demethylation inhibitor fungicides (McGrath et al. 1996), strobilurin (McGrath and Shishkoff 2003), and more recently to cyflufenamid (Pirondi et al. 2014). This issue is particularly acute for weed management because very few new herbicidal modes of action remain available (Heap 2014; Duke 2012). The increased likelihood of over-reliance on a narrow spectrum of molecules threatens the viability of conventional cropping systems where spatial and temporal diversity is low.

There is a debate on the relationship between use of pesticide doses lower than that recommended on the label, sublethal effects, the hormesis effect, and the evolution of resistance to pesticides. An aside to this question regards the converse situation - pesticide over-use - which probably contributes significantly to the evolution of pesticide-resistant pest biotypes. There are many situations where appropriate lower doses can be recommended without increasing the risk of inducing non-target resistance. Such a situation is reported with Phytophthora control in potato, as long as information on pest incidence, phenology, susceptibility to pesticides, and canopy structure, is included in decision-making (Cooke et al. 2011). In any case, there is no consistent evidence and no consensus among crop protection scientists that reduced pesticide dosages are related to resistance development. The authors believe that the debate is not precisely where it should be. Bearing in mind that no unequivocal relationship exists between pesticide dose and efficacy, a focus on efficacy levels 
rather than pesticide doses seems more pertinent (Kudsk 2014). The new vision of sustainable pesticide use focuses on a desirable control level that is then related to the selection pressure due to the biological activity and persistence of the active ingredients concerned.

Of course, the combination of chemically based tactics can help to reduce the evolution of resistance. For example, combining fungicides with different modes of action, application timing, and splitting applications did lead to more reliable resistance management strategies (van den Bosch et al. 2014a, b). It is also possible to monitor the occurrence of resistance to guide decision-making. This is precisely what the EuroBlight network mentioned above is engaged. It monitors Phytophthora infestans and provides updated multicountry information on new resistant isolates.

If we take a step back to look at the larger picture, we find that the root causes of increased risk of resistance are associated with the over-simplification and intensification of cropping systems (e.g., monocultures reliant on too few crop protection measures). This has been shown for weeds in continuous cropping situations (Neve et al. 2014). Focusing on weeds, Owen et al. (2014) conclude that merely modifying herbicide use will not yield lasting solutions to herbicide resistance in weeds. But this is probably true for the whole range of pests. To reduce the selection of resistant pest biotypes and lengthen the commercial lifespan of pesticides, farmers can strive for a higher level of IPM, consider the spatial distribution of tolerant varieties or non-host crops, and make full use of preventive measures (see Principle 1).

The root causes of increased risk of evolution of non-target resistance can be addressed by revisiting over-simplification and excessive intensification of cropping systems.

\subsection{Principle 8-evaluation}

Principle 8 encourages farmers to assess the soundness of the crop protection measures they adopt, and this is an important aspect of sound management. The delicate point here regards the evaluation criteria used. Farmer interviews showed that absolute yield - irrespective of profit — and total absence of pests, i.e., "clean" fields, are the two indicators of good crop protection practice most used among farmers and advisers (Lamine et al. 2009). Such traditional assessment methods can impede the development of alternatives. IPM-compatible assessment could cover multi-season effects, trade-offs with other compartments of production and economics, as well as human health and the environment. New IPM-adapted performance criteria and standards of reference could integrate these factors at a cropping system and agroecosystem level. Many positive effects of IPM strategies are multi-year, and effective evaluation therefore covers all crops of the rotation over more than one season. This is particularly pertinent to the management of weed seed banks, accumulation of soil-borne pathogens, resistance development of pathogens, and unpredictable insect outbreaks. As mentioned under Principle 4, the level of short-term control attained by chemical measures alone is not the standard by which "success" is gauged. A process of re-thinking and reassessing evaluation needs to be initiated. It would emphasize the evaluation of yield, yield stability, and profit over multiple years at the cropping system level. Lechenet et al. (2014) provide an example of an approach to assess pesticide use intensity at the cropping system level while taking into account multiple trade-offs. Research and extension work at the farm community level will develop new standards of reference, and performance criteria can become widely shared among farmers.

Sustainability in pest management calls for new evaluation criteria that take into account multi-season effects and a diversity of trade-offs, and can be widely shared among the farmer community.

\section{Conclusion}

With the Framework Directive on the sustainable use of pesticides, the European Union is embarking on achieving the mainstream use of IPM. Widespread adoption entails applying this sustainable pest management approach to a great diversity of biophysical and socio-economic farming situations. In addition to the diversity of farming situations, IPM practitioners contend with the intricacies of agronomic and ecological processes that are taken into account when reducing reliance on pesticides. In the face of such diversity, the search for a single universal "one-size-fits-all" pest control method is illusory. A set of general principles, on the other hand, makes up a flexible approach that can be adapted to local realities. That is why developing a pest management approach in terms of general principles makes sense. Applying the set of eight principles via an outcomes-based approach rather than enforcing intermediate goals may have the added benefit of encouraging adaptation and creativity while generating environmental and health benefits.

From the point of view of policy makers and program managers, the essential issue is to create the conditions that enable farmers to move along the IPM continuum over the long-term. Some European countries such as Germany, France, Denmark, Sweden, Italy, or Switzerland have supported IPM for many years. Other European countries are initiating this process. In the latter countries, bridging this gap to ensure that IPM principles are integrated into farming practices is all the more challenging. In Poland, Matyjaszczyk (2013) reviewed the challenges of wide implementation of IPM. She points out the need to strengthen state advisory services and find a balance between providing administrative support versus advice on sustainable practices. To generate synergies across Europe, a consortium of 21 countries recently 
created the ERA-Net C-IPM (c-ipm.org). This new structure is creating a network of funders to coordinate national IPMrelated programs.

Different countries are adopting different strategies to promote IPM. In a survey of 16 European Union Member States, the Health and Food Directorate General found that eight countries had explicit and dedicated national IPM programs (Dachbrodt-Saaydeh 2015). Other countries, such as France with its national action plan to reduce reliance on pesticides, embed IPM in other programs. Italy is establishing two formal levels of IPM, one is "basic" and compulsory and the other is "advanced" and voluntary (Galassi and Sattin 2014). The approach may be considered as part of a stepwise process along the IPM continuum. Several countries are developing cropspecific IPM guidelines inspired from the Integrated Production guidelines produced by the International Organization for Biological and Integrated Control (Baur et al. 2011). The survey mentioned above found 14 out of the 16 Member States having produced or planning to produce such guidelines (Dachbrodt-Saaydeh 2015). Further developing decision-support systems and their use across borders is receiving particular attention in European National Action Plans. The type of target selected for each National Action Plan also varies. France adopted a quantified pesticide reduction target expressed in terms of treatment frequency. Germany and Switzerland emphasize risk reduction and Denmark underscores health and environmental load. For the success of IPM as a sustainable management practice, what matters in the implementation approach is to allow the expression of the dynamic, multi-actor, systemic, and knowledge-intensive nature of IPM. Many of the IPM levers operate at a multi-year scale within a process of coordination among multiple actors and institutions. Research and extension efforts will therefore yield results with a certain lag time in an environment where more permanent types of funding, institutions, and educational initiatives are tailored to the needs of IPM.

With climate change and the acceleration of global trade, uncertainties and the frequency of emergence of existing and new pests will rise. Increasing our ability to quickly adapt to disturbance and climatic change will therefore become all the more important (Barzman et al. 2015; Lamichhane et al. 2014b). IPM, if understood as the dynamic application of principles to local situations rather than short-term single tactics, can generate the capacity to adapt and achieve the levels of resilience needed. The 15 institutional partners of ENDURE produced this paper to enrich the eight principles set by the European Union. We hope it will help identify those research, education, and extension efforts that will make the mainstreaming of flexible, locally adapted and practical IPM a more widespread reality.

Acknowledgments The authors of this paper are grateful to the 15 member organizations of the European network ENDURE for their support of this work.

\section{References}

Altieri MA, Nicholls CL (2003) Soil fertility management and insect pests: harmonizing soil and plant health in agroecosystems. Soil Tillage Res 72:203-211. doi:10.1016/S0167-1987(03)00089-8

Aluja M, Jimenez A, Camino M, Pinero J, Aldana L, Caserjon V, Valdes ME (1997) Habitat manipulation to reduce papaya fruit fly (Diptera: Tephritidae) damage: orchard design, use of trap crops and border trapping. J Econ Entomol 90:1567-1576. doi:10.1093/jee/90.6. 1567

Bartoli C, Lamichhane JR, Berge O, Guilbaud C, Varvaro L, Balestra GM, Vinatzer BA, Morris CE (2014) A framework to gauge the epidemic potential of plant pathogens in environmental reservoirs: the example of kiwifruit canker. Mol Plant Pathol 16:137-49. doi: 10.1111/mpp. 12167

Barzman MS, Bertschinger L, Dachbrodt-Saaydeh S, Graf B, Jensen JE, Jorgensen LN, Kudsk P, Messéan A, Moonen AC, Ratnadass A, Sarah JL, Sattin M (2014) IPM policy, research and implementation: European initiatives. In: Peshin R, Pimentel D (eds) Integrated pest management, experiences with implementation, global overview, vol 4. Springer, London, pp 415-428

Barzman M, Lamichhane JR, Booij K, Boonekamp P, Desneux N, Huber L, Kudsk P, Langrell SRH, Ratnadass A, Ricci P, Sarah J-L, Messean A (2015) Research and development priorities in the face of climate change and rapidly evolving pests. Sustain Agr Rev 17 (in press)

Baumgartner K, Steenwerth KL, Veilleux L (2008) Cover-crop systems affect weed communities in a California vineyard. Weed Sci 56: 596-605. doi:10.1614/WS-07-181.1

Baur R, Wijnands F, Malavolta C (2011) Integrated Production Objectives, Principles and Technical Guidelines. IOBC/WPRS Bulletin, Special Issue

Been TH, Schomaker CH, Molendijk LPG (2005) NemaDecide: a decision support system for the management of potato cyst nematodes. In: Haverkort AJ, Struik PC (eds) Potato in progress : science meets practice. Wageningen Academic Publishers, Wageningen, pp 154167

Benbrook CM, Groth E, Halloran JM, Hansen M, Marquardt S (1996) Pest management at the crossroads. Consumers Union, Yonkers, NY, $272 \mathrm{pp}$

BLW (Bundesamt für Landwirtschaft) (2013) Agrarbericht 2012. Published by Bundesamt für Landwirtschaft, Bern, Switzerland

Busi R, Vila-Aiub MM, Beckie HJ, Gaines TA, Goggin DE, Kaundun SS, Lacoste M, Neve P, Nissen SJ, Norsworthy JK, Renton M, Shaner DL, Tranel PJ, Wright T, Yu Q, Powles SB (2013) Herbicideresistant weeds: from research and knowledge to future needs. Evol Appl 6:1218-1221. doi:10.1111/eva.12098

Cantrell CL, Dayan FE, Duke SO (2012) Natural products as sources for new pesticides. J Nat Prod 75:121-1242. doi:10.1021/np300024u

Cook SM, Khan ZR, Pickett JA (2007) The use of push-pull strategies in integrated pest management. Annu Rev Entomol 52:375-400. doi: 10.1146/annurev.ento.52.110405.091407

Cooke LR, Schepers HTAM, Hermansen A, Bain RAJ, Bradshaw NJ, Ritchie F, Shaw DS, Evenhuis A, Kessel GJT, Wander JGN, Andersson B, Hansen JG, Hannukkala A, Nærstad R, Nielsen BJ (2011) Epidemiology and integrated control of potato late blight in Europe. Potato Res 54:83-222. doi:10.1007/s11540-011-9187-0

Costanzo A (2014) Increasing crop species and genetic diversity in organic wheat systems to improve weed reduction and yield. Dissertation, Scuola Superiore Sant'Anna, Pisa, Italy

Crowder DW, Jabbour R (2014) Relationships between biodiversity and biological control in agroecosystems: current status and future challenges. Biol Control 75:8-17. doi:10.1016/j.biocontrol.2013.10.010

Czaja K, Góralczyk K, Struciński P, Hernik A, Korcz W, Minorczyk M, Łyczewska M, Ludwicki JK (2015) Biopesticides-towards 
increased consumer safety in the European Union. Pest Manag Sci 71:3-6. doi:10.1002/ps.3829

Dachbrodt-Saaydeh S (2015) The policy perspective- - how EU Member States promote IPM implementation? Paper given at IPM innovation in Europe, Poznan, Poland January 15-17, 2015. www.pureipm.eu/node/431

DGAL (Direction Générale de l'Alimentation du Ministère de l'agriculture, de l'agroalimentaire et de la forêt) (2014) Note de suivi 2014 - Tendances du recours aux produits phytosanitaires de 2008 à 2013. http://agriculture.gouv.fr/IMG/pdf/121009_Note_de_suivi_ 2012 cle0a995a.pdf. Accessed 10 Feb 2015

Duke SO (2012) Why have no new herbicide modes of action appeared in recent years? Pest Manag Sci 68:505-512. doi:10.1002/ps.2333

ENDURE (2010a) Policy Brief No. 2 - the potential role of supermarket procurement strategies as drivers of IPM. ENDURE Publication. www.endure-network.eu/content/download/5964/45027/file/ Policy\%20Brief\%202.pdf Accessed 10 Feb 2015

ENDURE (2010b) Policy Brief No. 1-implementing IPM: a gradual path involving many stakeholders. ENDURE Publication. www. endure-network.eu/content/download/5963/45024/file/Policy\% 20Brief\%201.pdf. Accessed 10 Feb 2015

ENDURE (2010c) Policy Brief No. 3-biocontrol opportunities in the implementation of Integrated Pest Management. ENDURE Publication. www.endure-network.eu/content/download/5965/ 45030/file/Policy\%20Brief\%203.pdf Accessed 10 Feb 2015

Fernandez-Aparicio M, Amri M, Kharrat M, Rubiales D (2010) Intercropping reduces Mycosphaerella pinodes severity and delays upward progress on the pea plant. Crop Prot 29:744-750. doi:10. 1016/j.cropro.2010.02.013

Fourie JC (2010) Soil management in the Breede River Valley wine grape region, South Africa. 1. Cover crop performance and weed control. S Afr J Enol Vitic 31:14-21

Freier B, Zornbach W, Vilich V, Fink H (2012) Das modellvorhaben, demonstrationsbetriebe integrierter pflanzenschutz ist erfolgreich angelaufen. 58. Dtsch pflanzenschutztagung, vol 438. JuliusKühn-Archiv, Braunschweig, p 280

Galassi T, Sattin M (2014) Experiences with implementation and adoption of integrated pest management in Italy. In: Peshin R, Pimentel D (eds) Integrated pest management, experiences with implementation, global overview, vol 4. Springer, London, pp 487-512

Gao X, Wu M, Xu R, Wang X, Pan R, Kim HJ, Liao H (2014) Root interactions in a maize/soybean intercropping system control soybean soil-borne disease, Red crown Rot. PLoS ONE 9(5), e95031. doi:10.1371/journal.pone.0095031

Gerwick BC, Sparks TC (2014) Natural products for pest control: an analysis of their role, value and future. Pest Manag Sci 70:11691185. doi:10.1002/ps.3744

Gray ME, Levine E, Oloumi-Sadeghi H (1998) Adaptation to crop rotation: western and northern corn rootworms respond uniquely to a cultural practice. Recent Res Dev in Ent 2:19-31

Günter M, Pasquier D (2008) Verwirrungstechnik im weinbaueine erfolgsgeschichte. Schweiz Zeitschr Obst u Weinbau 21: 4-6

Hatcher PE, Melander B (2003) Combining physical, cultural and biological methods: prospects for integrated non-chemical weed management strategies. Weed Res 43:303-322. doi:10.1046/j.13653180.2003.00352.x

Haverkort A, Boonekamp PM, Hutten R, Jacobsen E, Kessel G, Visser R, Van der Vossen E (2008) Societal costs of late blight in potato and prospects of durable resistance through cisgenic modification. Potato Res 51:47-57. doi:10.1007/s11540-008-9089-y

Heap I (2014) The International Survey of Herbicide Resistant Weeds. www.weedscience.org Accessed 18 Oct 2014

Horticultural Development Company (2012) The SCEPTRE project and SOLA programme. HDC Soft Fruit Rev 2011/2012, p 5
International Plant Protection Convention (2010) International Standards for Phytosanitary Measures No. 5. Food and Agriculture Organization of the United Nations, Rome, Italy.

Jensen JE (2015) Perspectives on the implementation of IPM in EU- the advisory perspective. Paper given at IPM innovation in Europe, Poznan, Poland January 15-17, 2015. www.pure-ipm.eu/node/430

Kandhai MC, Booij CJH, Van der Fels-Klerx HJ (2011) Expert study to select indicators of the occurrence of emerging mycotoxin hazards. Risk Anal 31:160-170. doi:10.1111/j.1539-6924.2010.01486.x

Keller M, Gutjahr C, Mohring J, Weis M, Sokefeld M, Gerhards R (2014) Estimating economic thresholds for site-specific weed control using manual weed counts and sensor technology: an example based on three winter wheat trials. Pest Manag Sci 70:200-211. doi:10.1002/ ps. 3545

Khan ZR, Midega CAO, Bruce TJA, Hooper AM, Pickett JA (2010) Exploiting phytochemicals for developing a "push-pull" crop protection strategy for cereal farmers in Africa. J Exp Bot 61:41854196. doi:10.1093/jxb/erq229

Kohl J, Postma J, Nicot P, Ruocco M, Blum B (2011) Stepwise screening of microorganisms for commercial use in biological control of plantpathogenic fungi and bacteria. Biol Control 57:1-12. doi:10.1016/j. biocontrol.2010.12.004

Kudsk P (2014) Reduced herbicide doses: present and future in Proceedings 26th German Conference on Weed Biology and Weed Control, pp 37-44 10.5073/jka.2014.443.003

Kudsk P, Jensen JE (2014) Experiences with implementation and adoption of integrated pest management in Denmark. In: Peshin R, Pimentel D (eds) Integrated pest management, experiences with implementation, global overview, vol 4. Springer, London, pp $467-$ 486

Lamichhane JR (2014) Xanthomonas arboricola diseases of stone fruit, almond and walnut trees: progress toward understanding and management. Plant Dis 98:1600-1610. doi:10.1094/PDIS-08-14-0831FE

Lamichhane JR, Fabi A, Ridolfi R, Varvaro L (2013) Epidemiological study of hazelnut bacterial blight in central Italy by using laboratory analysis and geostatistics. PLoS ONE 8, e56298

Lamichhane JR, Barzman M, Booij K, Boonekamp P, Desneux N, Huber L, Kudsk P, Langrell SRH, Ratnadass A, Ricci P, Sarah JL, Messean A (2014b) Robust cropping systems to tackle pests under climate change. A review. Agron Sustain Dev 34 10.1007/s13593-0140275-9

Lamichhane JR, Varvaro L, Parisi L, Audergon JM, Morris CE (2014b) Disease and frost damage of woody plants caused by Pseudomonas syringe: seeing the forest for the trees. Adv Agron 126:235-295. doi:10.1016/B978-0-12-800132-5.00004-3

Lamine C (2011) Transition pathways towards a robust ecologization of agriculture and the need for system redesign cases from organic farming and IPM. J Rural Stud 27:209-219. doi:10.1016/j. jrurstud.2011.02.001

Lamine C, Barbier M, Buurma J, Blanc J, Haynes I, Noe E (2009) Societal assessment of current and novel low input crop protection strategies. Phase 2. http://www.endure-network.eu/content/ download/5455/42963/file/ENDURE_DR3.11-validated.pdf. Accessed 10 Feb 2015

LEAF (2103) Integrated Pest Management: what is IPM and what do the new guidelines cover? www.leafuk.org/resources/000/844/287/ IPM_What_is_IPM1.pdf Accessed 10 Feb 2015

Lechenet M, Bretagnolle V, Bockstaller C, Boissinot F, Petit MS, Petit S, Munier-Jolain NM (2014) Reconciling pesticide reduction with economic and Environmental Sustainability in arable farming. PLoS ONE 9(6), e97922. doi:10.1371/journal.pone.0097922

Lefebvre M, Langrell SRH, Gomez y Paloma S (2014) Incentives and policies for integrated pest management in Europe: a review. Agron Sustain Dev. doi:10.1007/s13593-014-0237-2 
Levay N, Terpo I, Kiss J, Toepfer S (2014) Quantifying inter-field movements of the western corn rootworm (Diabrotica virgifera virgifera LeConte) - a Central European field study. Cereal Res Commun. doi:10.1556/CRC.2014.0020

Levine E, Oloumi-Sadeghi H (1996) Western corn rootworm (Coleoptera: Chrysomelidae) larval injury to corn grown for seed production following soybeans grown for seed production. J Econ Entomol 89:1010-1016. doi:10.1093/jee/89.4.1010

Levine E, Spencer JL, Isard SA, Onstad DW, Gray ME (2002) Adaptation of the western corn rootworm to crop rotation: evolution of a new strain in response to a management practice. Am Enterp 48:94-107. doi:10.1093/ae/48.2.94

Mathijs E (2003) Social capital and farmers' willingness to adopt countryside stewardship schemes. Outlook on Agric 32:13-16

Matyjaszczyk E (2013) Plant protection in Poland on the eve of obligatory integrated pest management implementation. Pest Manag Sci 69:991-995. doi:10.1002/ps.3578

McDougall P (2013) R\&D trends for chemical crop protection products and the position of the European Market. A consultancy study undertaken for ECPA. www.ecpa.eu/information-page/regulatoryaffairs/publications-regulatory-affairs

McGrath MT, Shishkoff N (2003) First report of the cucurbit powdery mildew fungus (Podosphaera xanthii) resistant to strobilurin fungicides in the United States. Plant Dis 87:1007. doi:10.1094/PDIS. 2003.87.8.1007A

McGrath MT, Staniszewska H, Shishkoff N (1996) Fungicide sensitivity of Sphaerotheca fuliginea populations in the United States. Plant Dis 80:697-703

Melander B, Munier-Jolain N, Charles R, Wirth J, Schwarz J, van der Weide R, Bonin L, Jensen PK, Kudsk P (2012) European perspectives on the adoption of non-chemical weed management in reduced tillage systems for arable crops. Weed Technol 127:231-240. doi: 10.1614/WT-D-12-00066.1

Nave S, Jacquet F, Jeuffroy MH (2013) Why wheat farmers could reduce chemical inputs: evidence from social, economic, and agronomic analysis. Agron Sustain Dev 33:795-807. doi:10.1007/s13593013-0144-y

Neve P, Busi R, Renton M, Vila-Auib MM (2014) Expanding the ecoevolutionary context of herbicide resistance research. Pest Manag Sci 70:1385-1393. doi:10.1002/ps.3757

Norris RF (2005) Ecological bases of interactions between weeds and organisms in other pest categories. Weed Sci 53:909-913. doi:10. 1614/WS-04-048R1.1

Owen MDK, Beckie HJ, Leeson JY, Norsworthy JK, Steckeld LE (2014) Integrated pest management and weed management in the United States and Canada. Pest Manag Sci. doi:10.1002/ps.3928

Papp Komáromi J, Terpó I, Tokaji M (2007) Working together-farmer field schools in Hungary. Pestic News 78:8-9

Paredes D, Cayuela L, Campos M (2013) Synergistic effects of ground cover and adjacent vegetation on natural enemies of olive insect pests. Agric Ecosyst Environ 173:72-80. doi:10.1016/j.agee.2013. 04.016

Peters M, Freier B, Goltermann S, Holst F (2013) Use of checklists and a scoring system for evaluation of IPM implementation on demonstration farms. Future IPM in Europe. Book of Abstracts. http:// futureipm.eu/Abstracts Accessed 10 Feb 2015

Pillet E (2014) Réseau DEPHY-FERME: synthèse des premiers résultats à l'échelle nationale. APCA, 48 pages http://agriculture.gouv.fr/ IMG/pdf/2014 Synthese Resultats DEPHY cle848968.pdf Accessed 10 Feb 2015

Pirondi A, Nanni IM, Brunelli A, Collina M (2014) First report of resistance to cyflufenamid in podosphaera xanthii, causal agent of powdery mildew, from melon and zucchini fields in Italy. Plant Dis 98: 1581. doi:10.1094/PDIS-02-14-0210-PDN
PURE (2013) PURE 2nd Annual Newsletter. http://www.pure-ipm.eu/ sites/default/files/content/files/Annual\%20Newsletter nb2.pdf. Accessed 10 Feb 2015

Raboin LM, Ramanantsoanirina A, Dusserre J, Razasolofonanahary F, Tharreau D, Lannou C, Sester M (2012) Two-component cultivar mixtures reduce rice blast epidemics in an upland agrosystem. Plant Pathol 61:1103-1111. doi:10.1111/j.1365-3059.2012.02602.x

Racca P, Kleinhenz B, Zeuner T, Keil B, Tschöpe B, Jung J (2011) Decision support systems in agriculture: administration of weather data, use of geographic information systems (GIS) and validation methods in crop protection warning service. In: Jao C (ed) Efficient Decision Support Systems-Practice and Challenges From Current to Future, InTech, pp 331-354

Ratnadass A, Barzman MS (2014) Ecological intensification for crop protection. In: Ozier Lafontaine H, Lesueur Jannoyer M (eds) Sustainable agriculture reviews 14: agroecology and global change. Springer, Heidelberg, pp 53-81

Ratnadass A, Fernandes P, Avelino J, Habib R (2012) Plant species diversity for sustainable management of crop pests and diseases in agroecosystems: a review. Agron Sustain Dev 32:273-303. doi:10. 1007/s13593-011-0022-4

Rusch A, Valantin-Morison M, Sarthou JP, Roger-Estrade J (2010) Integrating crop and landscape management into new crop protection strategies to enhance biological control of oilseed rape insect pests. In: Ingrid W (ed) Biocontrol-based integrated management of oilseed rape pests. Springer, New York, pp 415-448. doi:10.1007/ 978-90-481-3983-5_17

Saghai Maroof MA, Webster RK, Allard RW (1983) Evolution of resistance to scald, powdery mildew, and net blotch in barley composite cross II populations. Theor Appl Genet 66:279-283. doi:10.1007/ BF00251159

Samietz J, Höhn H (2010) Nachhaltig regulieren. UFA-Revue 10:54-55

Samietz J, Graf B, Höhn H, Schaub L, Höpli HU, Razavi E (2011) Webbased decision support for sustainable pest management in fruit orchards: development of the Swiss system SOPRA. In: Jao C (ed) Efficient Decision Support Systems-Practice and Challenges From Current to Future, InTech, pp 373-388

Sapoukhina N, Paillard S, Dedryver F, Vallavieille-Pope C (2013) Quantitative plant resistance in cultivar mixtures: wheat stripe rust as a modeling case study. New Phytol 200:888-897. doi:10.1111/ nph.12413

Sattin M, Zanin G, Berti A (1992) Case history for weed competition/ population ecology: velvetleaf (Abutilon theophrasti) in corn (Zea mays). Weed Technol 6:213-219

Schenk A, Hunziker M, Kienast F (2007) Factors influencing the acceptance of nature conservation measures - a qualitative study in Switzerland. J Environ Manag 83:66-79. doi:10.1016/j.jenvman. 2006.01.010

Sikora K, Verstappen E, Mendes O, Schoen C, Ristaino J, Bonants P (2012) A universal microarray detection method for identification of multiple phytophthora spp. using padlock probes. Phytopathol 6: 635-645. doi:10.1094/PHYTO-11-11-0309

Snoeijer SS, Pérez-García A, Joosten MHAJ, De Wit PJGM (2000) The effect of nitrogen on disease development and gene expression in bacterial and fungal plant pathogens. Eur J Plant Pathol 106:493506, http://link.springer.com/content/pdf/10.1023\%2FA\% 3A1008720704105.pdf

Sojka RE, Karlen DL, Busscher WJ (1991) A conservation tillage research update from the coastal-plain soil and water conservation research center of South Carolina - a review of previous research. Soil Tillage Res 21:361-376, http://naldc.nal.usda.gov/naldc/ download.xhtml?id $=10758 \&$ content $=\mathrm{PDF}$

Stäubli A (1983) Le fruit d'une harmonie entre l'homme et la nature. Rev Suisse Vitic Arboric Hortic 15:317-318 
Stern VM, Smith RF, van den Bosch R, Hagen KS (1959) The integrated control concept. Hilgardia 29:81-101, http://ucanr.edu/repository/ fileaccess.cfm? article $=152499 \& \mathrm{p}=$ RNIYON

Szalai M, Kiss J, Sz K, Toepfer S (2014) Simulating crop rotation strategies with a spatiotemporal lattice model to improve legislation for the management of the maize pest Diabrotica virgifera virgifera. Agric Syst 124:39-50. doi:10.1016/j.agsy.2013.10.009

Underwood W, Melotto M, He SY (2007) Role of plant stomata in bacterial invasion. Cell Microbiol 9:1621-1629

Union E (2009a) Directive 2009/128/EC of the European parliament and of the council of 21 October 2009 establishing a framework for community action to achieve the sustainable use of pesticides. Off J Eur Union 52:71-86, http://eur-lex.europa.eu/legal-content/EN/ TXT/?uri=OJ:L:2009:309:TOC

Union E (2009b) Regulation (EC) No 1107/2009 of the European parliament and of the council of 21 October 2009 concerning the placing of plant protection products on the market and repealing council directives 79/117/EEC and 91/414/EEC. Off J Eur Union 52:1-50, http://eur-lex.europa.eu/legal-content/EN/TXT/?uri= OJ:L:2009:309:TOC

van den Bosch F, Oliver R, van den Berg F, Paveley ND (2014a) Governing principles can guide fungicide resistance management tactics. Annu Rev Phytopathol 52:9.1-9.21

van den Bosch F, Paveley ND, van den Berg F, Hobbelen P, Oliver R (2014b) Mixtures as a fungicide resistance management tactic. Phytopath 104:1264-1273. doi:10.1094/PHYTO-04-14-0121RVW

Van der Wolf JM, Van der Zouwen PS, Van der Heijden L (2013) Flower infection of Brassica oleracea with Xanthomonas campestris pv. campestris results in high levels of seed infection. Eur J Plant Pathol 136:103-111. doi:10.1007/s10658-012-0141-z

Van Gent-Pelzer MPE, Krijger M, Bonants P (2010) Improved real-time PCR assay for detection of quarantine potato pathogen Synchytrium endobioticum in zonal centrifuge extracts from soil and plants. Eur J Plant Pathol 126:129-133. doi:10.1007/s10658-009-9522-3

Vasileiadis VP, Sattin M, Otto S, Veres A, Pálinkás Z, Ban R, Pons X, Kudsk P, van der Weide R, Czembor E, Moonen AC, Kiss J (2011) Crop protection in European maize-based cropping systems: current practices and recommendations for innovative integrated pest management. Agric Syst 104:533-540, http://EconPapers.repec.org/ RePEc:eee:agisys:v:104:y:2011:i:7:p:533-540

Vasileiadis VP, Moonen AC, Sattin M, Otto S, Pons X, Kudsk P, Veres A, Dorner Z, Van der Weide R, Marraccini E, Pelzer E, Angevin F, Kiss J (2013) Sustainability of European maize-based cropping systems: economic, environmental and social assessment of current and proposed innovative IPM-based systems. Eur J Agron 48:1-11. doi:10. 1016/j.eja.2013.02.001

Villaverde JJ, Sevilla-Morán B, Sandín-España P, López-Goti C, AlonsoPrados JL (2014) Biopesticides in the framework of the European pesticide regulation (EC) No. 1107/2009. Pest Manag Sci 70:2-5. doi:10.1002/ps.3663

Walter AM (1996) Temporal and spatial stability of weeds. In: Brown H (ed) Proceedings Second International Weed Control Congress, pp 125-130

Zhu YY, Chen HR, Fan JH, Wang YY, Li Y, Chen JB, Fan JX, Yang SS, Hu LP, Leung H, Mew TW, Teng PS, Wang ZH, Mundt CC (2000) Genetic diversity and disease control in rice. Nature 406:718-722. doi: $10.1038 / 35021046$ 